
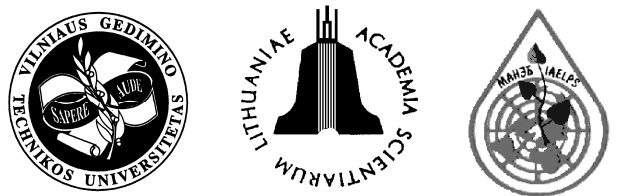

\title{
LUMINESCENCE STUDY OF DETERGENT OPTICAL BRIGHTENERS IN THE CONTEXT OF DEVELOPING OPTICAL ENVIRONMENTAL SENSORS FOR WATER QUALITY CONTROL
}

\author{
Ojars Balcers $^{1}$, Janis Teteris ${ }^{2}$ \\ ${ }^{1}$ Dept of Physics and Mathematics; \\ ${ }^{2}$ Institute of Solid State Physics, University of Latvia, Kengaraga iela 8, LV-1063 Riga, Latvia \\ E-mail: ojars.balcers@lu.lv; teteris@latnet.lv
}

Submitted 18 Apr 2006; accepted 18 May 2006

\begin{abstract}
Water quality and anthropogenic loads in many, but not all, cases are related. Some water quality monitoring programs analyse samples for the presence of Escherichia coli. These bacteria can come from humans and animals. Human-attributable effluent contains optical brighteners (OBs) from detergents. A convenient and affordable optical quantitative method giving a linear luminescence outcome over several orders of detergent concentrations in the water solution is demonstrated. The proposed method uses the common presence of OBs in detergents. Detergent concentration in water can be used as a surrogate indicator of resultant anthropogenic loads in water bodies. The proposed optical method with linear outcome over several ranges of detergent water concentrations is described.

Keywords: quality of water, environmental pollution optical measurements, anthropogenic loads control and reduction in water, effluent monitoring, optical brighteners (OBs), fluorescent whitening agents (FWAs), detergents, environmental toxicology.
\end{abstract}

\section{Introduction}

OBs in chemical industry are known in the detergent industry as fluorescent whitening agents (FWAs). FWAs are added to detergents in amount of a fraction of a percent. OBs with stilbene derivatives and carbocycles are widely used in textiles, papers and detergents in the EU. FWAs transform the light energy absorbed in the ultraviolet (UV) region into visible (blue) light contributing to a rise of lumiosity and whitening. OBs, after being absorbed by textile fibres, for the white wash ensure impeccable whiteness. They are discharged in substantial quantities with household wastewater.

The experimental determination disadvantages include selectivity and sensitivity of the non-expensive presence-absence approach. The method of high performace liquid chromatography is expensive. Due to wide proliferation numerous health impact assessments, e g, on allergic contact dermatitis and hormon-like effects of specific OBs have been carried out $[1,2]$. OBs sampling has been used for detecting sewage in karst groundwater [3].

Work objective was to investigate the possibility to quantify and compare the optical properties of different detergent water concentrations, ranging over serveral orders. The study included taking the absorption spectra and luminescence intensity of 55-7000 parts per million weight concentration range of detergent weight parts in the bidistilled water solution. The detergent under study is known to contain FWAs.
The presented investigation stage is a part of Materials Physics doctoral work dedicated to an optical study of the surface layer physical properties. The particular investigation stage illustrates the linear luminescence fit with OBs-detergent-water concentration.

Development of a low-cost quantitative luminescence method could serve as a comparable surrogate anthropogenic impact factor in water bodies. Further effort may advance the understanding of surfactant distribution in coastal environments and its connection to plankton and benthic organisms.

\section{Investigation object and methodology}

Investigation object was the range of water concentrations of detergent containing OBs. Different concentrations were obtained by mixing adding distilled water to the most concentrated liquid. All liquids are paper filtered. The following eight concentrations expressed in parts per million (ppm) weight of distilled water were used in measurements - 55, 110, 220, 440, 880, 1750, 3500,7000 . The detergent used contained OBs as was marked on the $600 \mathrm{~g}$ paper pack of Procter \& Gamble produced Ariel Automat Mountain Spring.

Absoprtion measurements were carried out by a standard procedure starting with an empty cuvette reference spectrum, then taking spectra in the order of increasing detergent luiquid concentration. The liquids were consequently poured into a UV grade kvarz cuvette. The absorption spectra were taken using UV-VIS Ocean 
Optics HR4000 High Resolution Spectrometer. Background subtraction and normalization were performed against a distilled water cuvette. The cuvette used was rectangular. The sample luminescence was induced by Kimmon He-Cd laser UV 325nm wavelength under standard holographic record approach conditions. The light entered the rectangular kvarz cuvette. The luminescence and transparency intensities for all the samples were synchonously recorded by Nova II Ophir power meter and by a photoelectron multiplier. The photoelectron multiplier was used because of low signal sensitivity considerations.

Colour optical glass filters $5 C 7$ (light, transmit above $340 \mathrm{~nm}$ ) and УФC6 (dark, transmit above $280 \mathrm{~nm}$ and below $420 \mathrm{~nm}$ ) (ГOCT 9411-60) were used to separate the UV and VIS signal components. Lumiscence intensity experimental setup is shown in Fig 1. Sample change is performed by removing the rectangular kvarz cuvette and replacing the luiquid with that of a larger concentration.

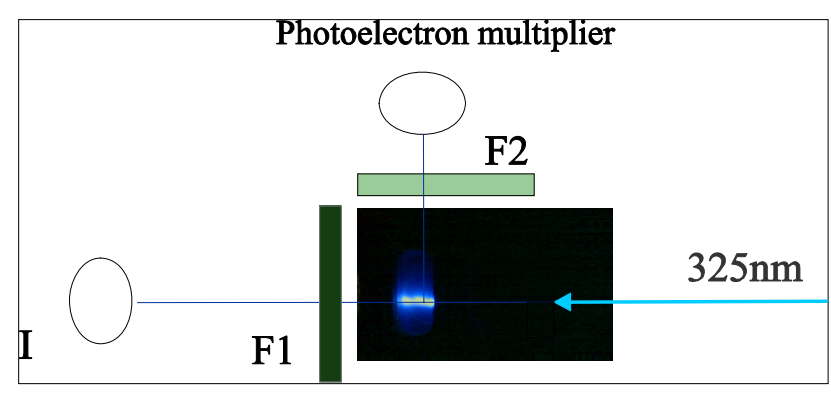

Fig 1. Experimental setup. He-Cd laser light of $325 \mathrm{~nm}$ falls on a sample in a kvarz cuvette. UV light is absorbed and blue visible light emitted by a sample. Transmission and luminescence are measured simultaneously. Colour optical glass filters used to separate the UV and VIS light components were F1- УФC6 (transmit above $280 \mathrm{~nm}$ and below $420 \mathrm{~nm}$ ) and F2- БC7 (transmit above $340 \mathrm{~nm}$ )

For experiments a cw UV source of $325 \mathrm{~nm}$ was available. The luminescence spectra after inducing with the UV source were not measured, but may be done, if a UV source of other UV wavelength becomes available.

\section{Results and discussion}

The presented experimental setup demonstrates our experimental method when a laser beam of $325 \mathrm{~nm}$ falls on a sample in a kvarz cuvette. UV light is absorbed, and a blue visible light is emitted by the sample. This allows to measure conveniently and simultaneously intensity and lumiscence in two different spectral areas. Colour optical glass filters allow separation of the UV and VIS regions and thus the measuring of interesting regions for luminescence and transmission specters.

This setup provides for a very convenient and experimentally efficient comparison of optical outcomes. We propose that an experimental approach can be used as a method of rapid determination and comparison of anthropogenic loads in water bodies and thus serve as a surrogate indicator of resultantanthopogenic pollution in effluent. To our knowledge this is the first time when an optical method with a linear outcome over several ranges of detergent water concentrations is described. The linear optical outcome is very convenient for different water samples to be compared. There are few producers of detergents that dominate the regional market segment. The detergents contain optical brighteners that yield optically conveniently definable properties and uniquely identify anthropogenic origin in effluent.

Some water quality monitoring programs analyse samples for the presence of Escherichia coli. These bacteria can come from humans and animals. Humanattributable effluent contains optical brigheteners from within detergents.

Fig 2 shows optical density (normalized absorption) spectra of samples.

It can be seen that for a detergent with optical brighteners clear UV absorption maxima are present. The authors propose that this shows well-known optical properties of OBs [1]. Both the absorption maximum position in the UV region and the form change with the concentration change. A maximum shift agrees well with the concentration change. Importantly, absorption is clearly present even at the most diluted concentration of $55 \mathrm{ppm}$. This indicates that the method is sensitive in tens of ppm dilution range. The authors believe that further sensitivite improvement of few orders down to the ppb sensitivity range may lie with the option of using the UV laser source at a maximum absorption region of 220-230 nm. Detergent concentrations in human-attributable effluent are most likely diluted. The diluted range measured would be the range of the most applicable field of experimental interest. For comparison, the hand-wash concentration range can be indicated to correspond to curves 7 and 8 . The result suggests that the investigation object can be conveniently studied using optical methods.

The absorption maxima are located in the UV range of 230-250 nm. The UV and VIS region spectral methods correspond to the transitions of valence electrons. The absorption maximum shifts to higher wavelengths corresponding to the concentration increase. This corresponds well with the characteristic IR spectral shift corresponding to the concentration change [4] and the properties change along with the composition change of a solid [5, 6]. The spectral shift manifests itself as compared to the corresponding change of the lines halfwidths or the change in thermal properties. For our task of comparing spectra of solutions over several concentration ranges, even qualitatively the shift and change in line halfwidths are well observable, for quantitative comparing purposes, absorption data appear still to be unsuitable for comparable, blind water sample testing in real-life conditions. The second experimental set included luminescence measurements that were induced by an available in laboratory coherent light source in the UV region - $325 \mathrm{~nm}$ wavelength of the He-Cd laser. Fig 3 shows transmission and luminescence dependence for the same samples. Transmission was measured using an optical power meter. It was in the milliwat range. Simultaneous luminescence intensity measurements were carried out with a photoelectron multiplier, arbitrary units. Experimental corre- 


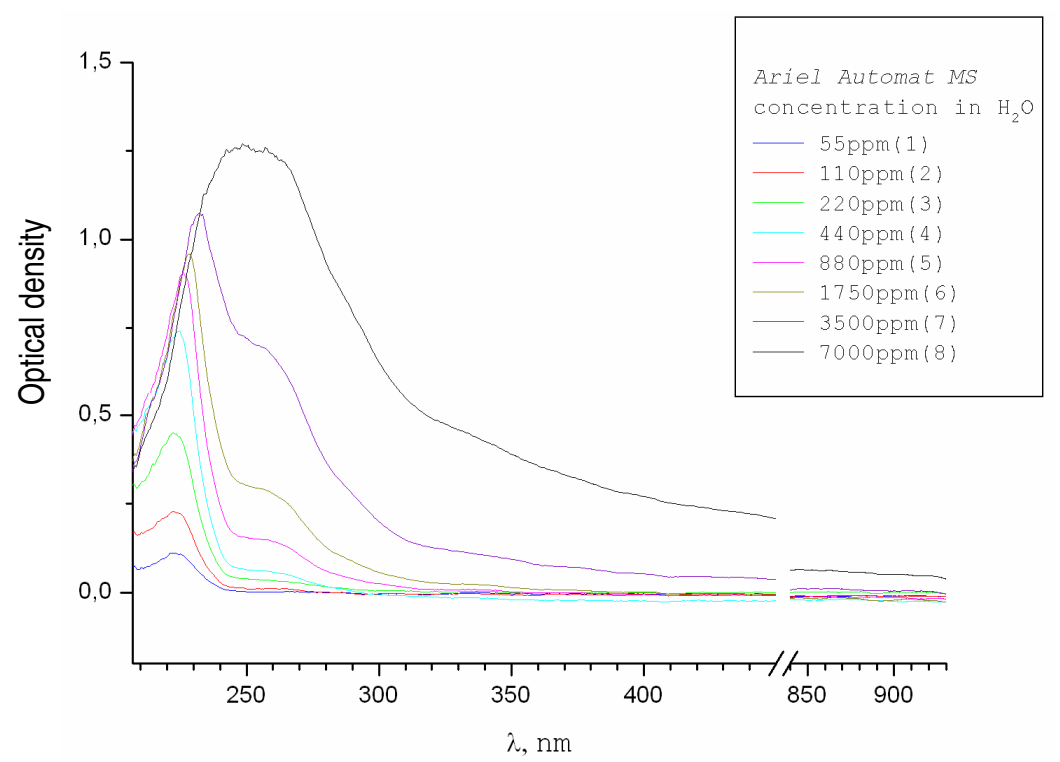

Fig 2. Optical density dependance for different detergent concentrations in distilled water solution. Sample liquids were paper-filtered and then poured into kvarz container for measurements

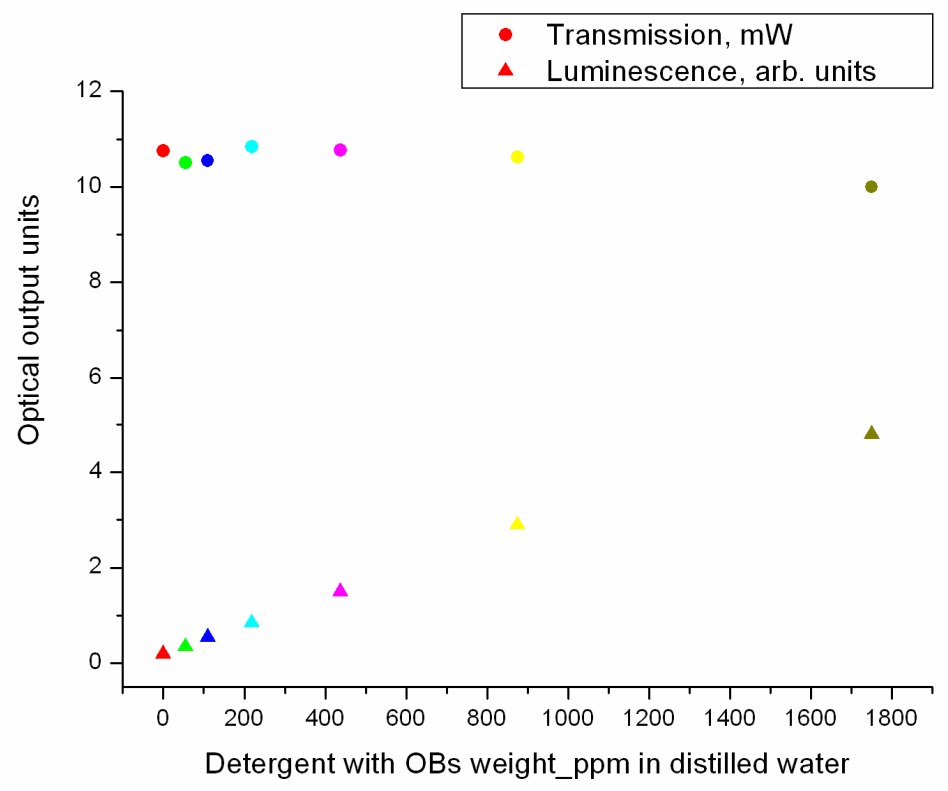

Fig 3. Transmission and luminescence dependence of study object concentration

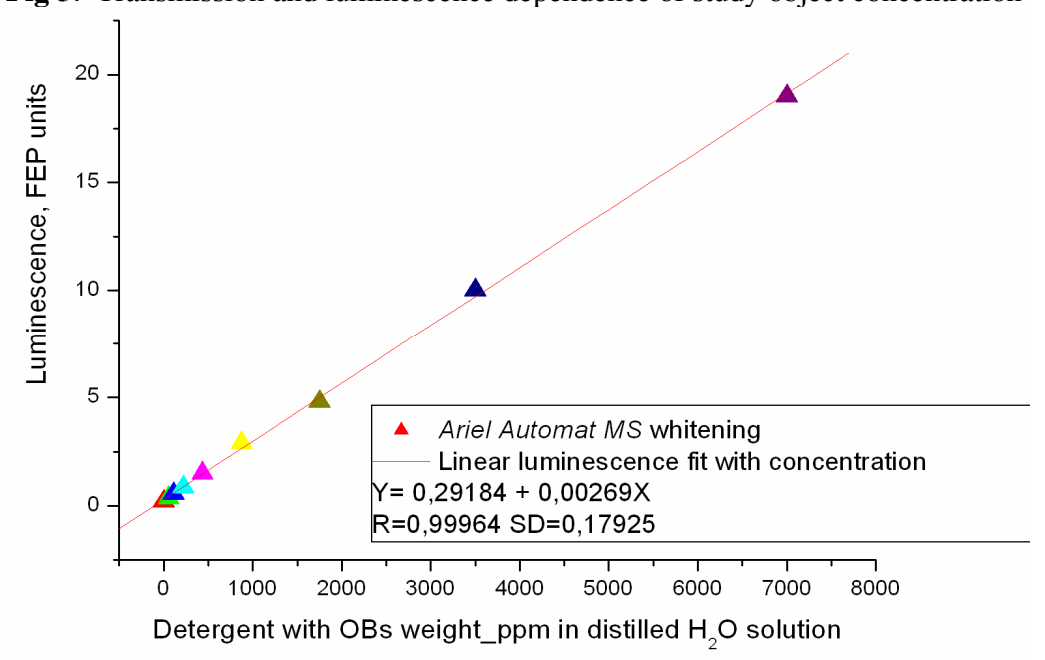

Fig 4. Experimental luminescence linear fit for 55-7000 ppm weight concentration range of detergent containing OBs and distilled water filtered solution 
spondence usable for comparison purposes of 19 photoelectron multiplier arbitrary units to $2,5 \mathrm{~mW}$ was found at a $325 \mathrm{~nm}$ inducing wavelength. The result indicates that the concentration dependence of transmission intensity for dilute concentration range with the present experimental setup does not present a consistent change pattern. One of the reasons is a small transmission change. This together with an experimental need for each measurement to empty and fill the sample-holder - cuvette limits transmission specter usage for the experimental concentration range under the current experimental setup. For a future work, a system can be improved, so that the sample change does not require cuvette removal. Such an approach could be used for sensitivity increase for the transmission method when the transmissivity is to be used for determining OBs presence in effluent.

For effluent containg Obs, the luminescence method gives all the required quantitative comparability for the field testing.

Under the current experimental practice the luminescence could be conveniently used for the purpose of quantitative and comparison measurements, as the luminescence intensity measured was well fit with a linear line for the whole sampled range of 55-7000 ppm in weight. The result is displayed in Fig 4. Very good linear fit for luminescence stands out as compared with a less pronounced change in transmissivity over the experimentally measured range of concentrations. The luminescence method is particularly well suited for determining OBs presence in effluent.

Further increase in sensitivity seems to be achievable with the current approach. A possibility to reach the ppb range may experimentally lie with using a UV source closer to the FWAs absorption maxima range.

The reason we follow the transmisivity sensitivity experiments when an efficient luminescence method has been demonstrated, is that apart from a specific single problem of effluent anthropogenic load comparing an opportunity to use the Optical Recording Laboratory experimental experience to record subwavelength-period gratings in amorphous chalcogenide thin films [7-9] might prove perspective for lattice tunable environmental and evanescent-wave sensors. As the ability to fabricate low-loss photoinduced channel waveguides in chalcogenide glasses have been demonstrated [10], advances towards online distributed environmental monitoring sensor networks may prove attainable with continued investigations.

\section{Conclusions}

1. A luminescence experiment can be readily used for determining the presence and concentration of detergents containing optical brighteners in field experiments.
2. An optical measurement approach appears promising to be used as an anthropogenic load surrogate indicator in water bodies.

3. Further work lies with the development of the luminescence method, so that cuvette removal is not needed when changing a sample.

4. For tunable selectivity considerations subwavelength-period gratings in amorphous chalcogenide thin films may replace a kvarz rod used.

\section{Acknowledgments}

The support of Riga Municipality grant is acknowledged. The first author wishes to kindly acknowledge the support of the European Social Fund.

\section{References}

1. Health assessment of specific stilbene derivatives used as textile auxiliaries or in detergents. Bundesinstitut für gesundheitlichen Verbraucherschutz und Veterinarmedizin, BgVV, October 2001.

2. Grajewski, B. et al. Evaluation of reproductive function among men occupationally exposed to a stilbene derivative. American J Ind Med, Vol 9, 1996, p. 49-57.

3. Aley, T. Optical Brightener Sampling: A Recoonaissance Tool for Detecting Sewage in Karst Groundwater. Hydrological Science and Technology: Short Papers, Vol 1, No 1, 1985, p. 45-48.

4. West, A. R. Solid State Chemistry and its Applications. John Wiley and Sons Ltd., 1984.

5. Chang, I. T. H.; Balcers, O.; Cantor, B. The Effect of Added Mo on the Crystalline Behaviour of Rapidly Solidified Fe70Cr30B10 Alloys. International Journal of Rapid Solidification, Vol 9, No 1, 1995, p. 63-73.

6. Stradins, P.; Balcers, O.; and Gerbreder, V. Photoinduced Amorphous <> Crystalline Transitions in SbxSe1-x Films. In: Materials Research Society Symposium Proceedings, Vol 321, 1994. 429 p. Crystallization and Related Phenomena in Amorphous Materials - Ceramics, Metals, Polymers, and Semiconductors, Boston.

7. Teteris, J.; and Reinfelde, M. Immersion holographic recording of subwavelength gratings in amorphous chalcogenide films. Journal of Optoelectronics and Advanced Materials, Vol 7, No 5, 2005, p. 2581-2586.

8. Balcers, O.; Reinfelde, M.; and Teteris, J. In: Proceedings ICANS21, Lisbon, Portugal, 2005.

9. Teteris, J.; and Reinfelde, M. Application of Amorphous Chalcogenide Semiconductor Thin Films in Optical Recording Technologies. Journal of Optoelectronics and Advanced Materials, Vol 5, No 5, 2003, p. 1355-1360.

10. Ramachandran, S.; and Bishop, S. G. Photoinduced Integrated-Optic Devices in Rapid Thermally Annealed Chalcogenide Glasses. IEEE Journal of Selected Topics in Quantum Electronics, Vol 11, No 1, 2005, p. 260-270. 


\section{OPTINIŲ BALIKLIŲ SKALBIMO PRIEMONĖSE LIUMINESCENCIJOS TYRIMAS SIEKIANT SUKURTI OPTINIUS APLINKOSAUGINIUS VANDENS KOKYBĖS KONTROLĖS JUTIKLIUS}

\section{O. Balcers, J. Teteris}

\section{Santrauka}

Vandens kokybė ir jo antropogeninis turinys daugeliu atvejų, nors ir ne visada, yra susiję. Kai kurios vandens kokybės stebėsenos sistemos analizuoja mėginius ir nustato, ar juose yra Escherichia coli bakterijų. Šios bakterijos gali būti žmogiškosios ir gyvūninès kilmès. Nuotekose, kurios susidaro dèl žmonių veiklos, esti optinių balikliu (OB) iš skalbimo priemonių. Pateiktas patogus ir nebrangiai atsieinantis optinis kvantinis metodas, kurị taikant gaunami tiesiniai liuminescencijos įverčiai, esant skirtingoms skalbimo priemoniu koncentracijoms vandenyje. Siūlomas metodas taikomas skalbimo priemonése naudojant OB. Skalbimo priemonių koncentracijos vandenyje duomenis galima panaudoti kaip pakaitini vandens telkinių užterštumo rodiklị. Aprašomas optinio metodo taikymas bei tiesiniai įverčiai, gauti tiriant įvairias skalbimo priemonių koncentracijas vandenyje.

Prasminiai žodžiai: vandens kokybė, optiniai aplinkos taršos tyrimai, antropogeninio turinio vandenyje kontrolè ir mažinimas, nuotekų stebėsena, optiniai balikliai, skalbimo priemonės.

\section{ИССЛЕДОВАНИЕ КОНЦЕНТРАЦИИ ОПТИЧЕСКИХ ОТБЕЛИВАТЕЛЕЙ В РАСТВОРАХ МОЮЩИХ СРЕДСТВ ПО СПЕКТРАМ ЛЮМИНЕСЦЕНЦИИ ДЛЯ КОНТРОЛЯ КАЧЕСТВА ВОДЫ}

\section{О. Балцерс, Я. Тетерис}

Резюме

Качество воды и культурные отложения во многих случаях взаимосвязаны. Иногда при анализе качества воды проводятся исследования на наличие бактерий Escherichia coli, которые могут появляться в отходах, связанных с человеческой жизнедеятельностью, и в отходах животных. Сточные отходы, связанные с жизнедеятельностью человека, содержат оптические отбеливатели из моющих веществ. В настоящей работе описывается практичный и удобный оптический метод для количественной оценки концентрации моющего вещества в водном растворе по линейному выходу люминесценции оптических отбеливателей. Концентрация моющих веществ может быть использована в качестве непрямого индикатора наличия отходов человеческой жизнедеятельности в сточных водах.

Ключевые слова: качество воды, оптические измерения загрязнения окружающей среды, мониторинг сточных загрязнений, оптические отбеливатели, флюоресцирующие отбеливающие реагенты, моющие средства, токсикология окружающей среды.

Ojars BALCERS. Master, doctoral student, Dept of Physics and Mathematics, University of Latvia.

Master of Science (materials science and mechanics), Michigan State University, 1995. Publications: author and co-author of 4 research papers. Research interests: optical and holographic sensors, water quality.

Janis TETERIS. Dr, head of Laboratory of Optical Recording, Institute of Solid State Physics, University of Latvia.

Doctor of Physics, University of Latvia. Publications: author of more than 80 research papers. Research interests: photoinduced processes in amorphous chalcogenide materials, R\&D of holographic materials for hologram recordings and storage. 